\title{
Factors related to voluntary external turnover of nursing professionals*
}

\section{Fatores relacionados à rotatividade externa voluntária de profissionais de enfermagem Factores relacionados con la rotatividad externa voluntaria de profesionales enfermeros}

How to cite this article:

Balabanian YCC, Monteiro MI. Factors related to voluntary external turnover of nursing professionals. Rev Esc Enferm USP. 2019;53:e03427. DOI: http:// dx.doi.org/10.1590/S1980-220X2017033403427

\section{Yvete Carvalho Chaves Balabanian ${ }^{1}$ Maria Inês Monteiro²}

* Extracted from the dissertation: "Rotatividade dos profissionais de enfermagem de um hospital universitário público", Faculdade de Enfermagem, Universidade Estadual de Campinas, 2014

${ }^{1}$ Universidade Estadual de Campinas, Faculdade de Enfermagem, Programa de Pós- Graduação, Campinas, SP, Brazil.

${ }^{2}$ Universidade Estadual de Campinas, Faculdade de Enfermagem, Campinas, SP, Brazil.

\section{ABSTRACT}

Objective: To analyze the factors related to the turnover of nursing professionals of a public teaching hospital. Method: Descriptive, exploratory, retrospective study with quantitative analysis conducted with workers from a public teaching hospital. The analysis used a data collection instrument from the service, applied at the time of the voluntary resignation of the professional. Results: 223 nursing professionals participated in the study. The factors that led to voluntary turnover were the employment bond, age and the association of both. The majority of professionals were young adults, in a high productivity phase, which increases willingness to seek challenges in the labor market and professional improvements. Conclusion: Turnover is multifactorial and influenced by economic, social and political aspects. Reducing inequalities in working conditions, which generate dissatisfaction, such as different employment bonds for professionals who have the same function and perform the same activities, is fundamental to reduce turnover.

\section{DESCRIPTORS}

Nursing; Personnel Turnover; Job Satisfaction; Nursing Staff, Hospital; Health Management. 


\section{INTRODUCTION}

Professional turnover is defined as the movement of employees in and out an organization and the labor market. It is quantified by the number of people entering and leaving an organization or the ratio between the number of admissions and resignations of professionals ${ }^{(1)}$. The turnover can be external, referring to the professionals who leave the organization for various reasons, or internal, which is the transfer to positions of other areas or units within the same institution $^{(2)}$. In addition, resignation may be voluntary, as a consequence of a personal decision of the professional, or involuntary, when the resignation is a decision of the organization ${ }^{(3)}$. The present study considered volunteer external turnover, that is, cases in which professionals voluntarily asked for resignation.

The high turnover of nursing professionals is an important factor for the institutions due to the high costs involved in the resignation and admission processes, since it requires planning, selection tests, continuing education and dedication from the supervision team to the specific orientations of each area, using human, physical and material resources ${ }^{(4-5)}$.

Beyond the financial aspect, turnover generates indirect impacts such as the reduction in the efficiency of the institution, decrease of the productivity of the team and loss of competent and skilled professionals. In addition, this event leads to overload of the professionals of the work unit, demands time to restructure the team, requires overtime hours, and reflects on the motivation of the professionals and on the organizational climate ${ }^{(6)}$.

The turnover of nursing professionals is a matter of international concern. The factors that are frequently mentioned as determinants in the literature are those related to professional satisfaction and management aspects. In addition, financial consequences are highlighted. Despite the existence of studies that analyze determinants and consequences of turnover, there is a necessity for more research to analyze the intention to leave the employment and the effective institutional turnover ${ }^{(7-8)}$.

Once managers recognize, value and praise the skills of nursing professionals in the delivery of quality clinical practice, they help employees feel that their work is appreciated and valued. Consequently, the result is greater job satisfaction ${ }^{(9)}$. The characteristics of institutions can affect even the quality of life of employees ${ }^{(10)}$.

Thus, the objective of this study was to analyze the factors related to the turnover of nursing professionals in a public teaching hospital. This study provides reflections on the turnover of nursing professionals, aiming to find better and innovative work possibilities, providing the citizens safety and quality in health care.

\section{METHOD}

\section{TYPE OF STUDY}

Descriptive, exploratory, retrospective study with quantitative approach $^{(11)}$, conducted in the Nursing Department of a high complexity public teaching hospital with approximately 400 beds, located in the state of São Paulo, in the
Southeast region of the country. The hospital holds teaching, research and care activities.

\section{Population}

The study population consisted of nurses, nursing technicians and nursing assistants, who belonged to the Nursing Department and who voluntarily asked for resignation from the institution, in the period from January $1^{\text {st }}, 2010$ to December 31 $3{ }^{\text {st }}, 2013$. Those who were in the process of transferring a work contract, that is, the professionals with a work contract by the University's Development Foundation who had voluntarily resigned to be admitted with a work contract tied to the university, were excluded. Professionals whose reason for turnover was retirement or death were also excluded. For a greater accuracy of the research, the population was considered, not the sampling.

The analysis of voluntary external turnover of nursing professionals from the Nursing Department of the university hospital studied is relevant because it is a large team. There are approximately 1,550 nursing professionals, out of the total of 3,100 professionals of the institution. In addition, it is a high-complexity, high-demand hospital that uses specialized therapies and health technologies.

The nursing professionals are employed in the hospital through a public contest of the university or through a selection process of the foundation. The employment bond with the university provides employment stability, a career plan and social benefits. The employment by the foundation does not provide stability, the salary and benefits are lower, some benefits do not exist and there is no career plan established. The foundation is a legal entity of private law and its activities include, among others, purchasing goods and hiring personnel. For both employment bonds, the resignation process from the Nursing Department is similar.

\section{Data collection}

The research was carried out based on the analysis of the information in the data collection instrument, which is a structured questionnaire from the Nursing Department applied during the resignation process to nursing professionals who resigned from their function from 2010 to 2013. Data analysis was performed in 2014.

The factors related to the dyad resignation and turnover of nursing professionals, referring to the period from 2010 to 2013 , were analyzed. The analysis considered data related to voluntary resignation in the various units of the hospital, which included professional category, time working in the institution, employment bond, contract by the university or by the foundation, level of education, age, gender, place of work, work shift, presence of health problem, presence of another employment bond, year of resignation and reasons for the resignation.

The categorical variables and measures of central tendency of the data collection instrument were described by absolute value and percentage and dispersion was used for the quantitative variables. 


\section{DATA ANALYSIS}

For the statistical analysis, the data were inserted in a spreadsheet in Microsoft Excel ${ }^{\oplus}$ and analyzed by statistical tests in the program Statistical Analysis System - SAS ${ }^{\varpi}$ 9.2. The comparisons involving categorical variables in relation to the variable age at resignation were performed using the Mann-Whitney test for the variables that had two categories and the Kruskal-Wallis test for the variables with more than two categories, followed by Dunn's post-test. The chisquare test was applied to study the associations between the variables of resignation and the categorical variables. For the cases in which at least $20 \%$ of the boxes in the table of expected values had a score lower than five, the Fisher exact test was applied. A significance level of less than 5\% was considered for all analyzes, that is, the data were statistically significant when $\mathrm{p}<0.05^{(12)}$. In the statistical analysis, the variables that did not contain the information were not considered in the percentages and recorded as 'not informed'.

\section{ETHICAL ASPECTS}

The development of the study met national and international standards of research ethics involving human beings. The project was submitted to evaluation by the Research Ethics Committee of the School of Medical Sciences of the Universidade Estadual de Campinas in 2012, according to resolution n. 466/12 of the National Health Council and approved under no. $259.999^{(13)}$.

\section{RESULTS}

The study population consisted of 223 nursing professionals, with resignation between 2010 and 2013, in the following proportion: 52 professionals (23.3\%) resigned in 2010, $63(28.3 \%)$ in 2011, $71(31.8 \%$ \%) in 2012 and 37 $(16.6 \%)$ in 2013. Regarding the proportion of voluntary resignation by the total of resignation by category, $39.5 \%$ of resignation was of nurses, $34.2 \%$ of nursing technicians and $25.8 \%$ of nursing assistants.

Most professionals (63.3\%) reported having two simultaneous jobs and $48.4 \%$ considered their income as the 'work force' of their family. The majority (83.6\%) had a prior employment bond in Campinas or in the metropolitan region of Campinas. As for the means of commuting, $49.8 \%$ used a car, $18.8 \%$ used charter buses from the university and $12.6 \%$ used common bus lines. Part of the workers $(27.8 \%)$ reported having had some type of health problem during their employment contract in the hospital. The socio-demographic and professional characteristics are presented in Table 1.

The mean age of the study population was 33.6 years (SD 7.8), and the median was 31.4 years. In the 4 -year historical series, the mean ranged from 32.8 to 34.1 years (SD 7.3 to 8.7), and the median ranged from 30.3 to 32.5 years.

The mean length of stay in the institution was 3.1 years (SD 4.1). The shortest time working in the institution was a resignation on the day of hiring, considered zero work days, and the highest was 25 years. The first quartile presented
0.4 year and median of 1.5 years, and the third 4.4 years. In the 4-year historical series, the median ranged from 1.1 years in 2012 to 3.5 years in 2010, and the mean ranged from 2.3 years (SD 3.1) in 2012 to 4.6 years (SD 5.0) in 2010. The first quartile ranged from 0.3 in 2012 and 2013 to 0.8 in 2010, and the third quartile ranged from 2.7 years in 2012 to 6.6 years in 2010 .

Table 1 - Distribution of resignation professionals according to socio-demographic and professional characteristics - Campinas, SP, Brazil, 2014.

\begin{tabular}{|c|c|c|}
\hline Variable & $\mathbf{n}$ & $(\%)$ \\
\hline \multicolumn{3}{|l|}{ Gender } \\
\hline Female & 199 & 89.2 \\
\hline Male & 24 & 10.8 \\
\hline \multicolumn{3}{|c|}{ Type of course/institution of professional training } \\
\hline Public & 88 & 42.7 \\
\hline Private & 118 & 57.3 \\
\hline Notinformed & 17 & \\
\hline \multicolumn{3}{|l|}{ Category } \\
\hline Nurse & 47 & 21.1 \\
\hline Nursing technician & 168 & 75.3 \\
\hline Assistant & 8 & 3.6 \\
\hline \multicolumn{3}{|l|}{ Employment bond } \\
\hline University & 96 & 43.0 \\
\hline Foundation & 127 & 57.0 \\
\hline \multicolumn{3}{|l|}{ Area/Allocation } \\
\hline Adult Hospitalization Unit & 112 & 50.2 \\
\hline Intensive Care Unit & 28 & 12.5 \\
\hline Referral Emergency Unit & 27 & 12.1 \\
\hline Pediatric Hospitalization Unit & 24 & 10.8 \\
\hline Outpatient clinics & 10 & 4.5 \\
\hline Surgery and Material Center Sterilization & 22 & 9.9 \\
\hline \multicolumn{3}{|l|}{ Work shift } \\
\hline Morning & 68 & 31.6 \\
\hline Afternoon & 89 & 41.4 \\
\hline Night & 53 & 24.7 \\
\hline Administrative & 5 & 2.3 \\
\hline Not informed & 8 & - \\
\hline \multicolumn{3}{|l|}{ Time working in the institution (in years) } \\
\hline Up to 1 and fractions & 123 & 55.2 \\
\hline 2 to 4 & 53 & 23.8 \\
\hline 5 to 9 & 37 & 16.6 \\
\hline 10 to 14 & 4 & 1.8 \\
\hline 15 to 19 & 3 & 1.3 \\
\hline 20 or more & 3 & 1.3 \\
\hline
\end{tabular}

Note: $(n=223)$.

Regarding the employment bond, $21.3 \%$ of nurses were hired by the university and $78.7 \%$ by the foundation. Among the nursing technicians and assistants, $48.9 \%$ had an employment bond with the university and $51.1 \%$ with the foundation. 
The variable "presence of health problem while working in the hospital" was answered affirmatively by $28.7 \%$ (62 subjects), who confirmed the existence of a health situation; five workers reported more than one health problem. The most prevalent health problem was musculoskeletal disorder (43.9\%, 18 subjects), followed by infectious diseases (conjunctivitis, sinusitis, pharyngeal conditions, herpes, varicella, mumps and dengue), with 12 subjects (29.4\%).

Among the reasons mentioned by the professionals as motivation for their resignation, $26 \%$ were personal reasons, $9 \%$ another job outside nursing, $8.5 \%$ the salary, $4.5 \%$ health problem, $2.7 \%$ the working conditions, $2.2 \%$ dissatisfaction with leadership, $1.4 \%$ adaptation problems with the team, $0.9 \%$ dissatisfaction with the interpersonal relationship and $56.1 \%$ claimed other reasons.

Salaries differed significantly according to the employment bond, with a variation of $33.5 \%$ between university and foundation contracts, as shown in Table 2.
The reasons given by the subjects are presented below. In the study, we counted each time a reason was mentioned. The same subject may have claimed one or more reasons, so the number of reasons is the number of times that it was mentioned, according to Table 3 .

The association between the variable age at resignation with the other variables was statistically significant for the variables "employment bond" ( $\mathrm{p}$-value $=0.0177$ ), "time working in the hospital" ( $\mathrm{p}$-value $=0.0262)$, "reason: personal problem" ( $p$-value $=0.0009)$ and "work force", an expression that designated a significant financial contribution to the family ( $p$-value $=0.0140$ ), according to Table 4 .

The association of the variable "reason for resignation: salary" was statistically significant for the variables "employment bond" ( $p$-value $=0.0412$ ) and "professional category" $(p$-value $=0.0015)$. The association of the variable "reason for resignation: another job" was statistically significant for the variables "employment bond" ( $\mathrm{p}$-value=0.0395), "time working in the hospital" ( $\mathrm{p}$-value $=0.0280)$, and "health problem" (p-value $=0.0307)$.

Table 2 - Salaries of nursing professionals of the Public Teaching Hospital of the São Paulo state, according to the employment bond - Campinas, SP, Brazil, 2014.

\begin{tabular}{lcccc}
\hline \multicolumn{4}{c}{ Salaries of nursing categories according to employment bond by the university and by the foundation } \\
\hline & University & Foundation & Salary Difference Value of in \% & Value of salary difference \\
\hline Nurses & $\mathrm{R} \$ 4,972.01$ & $\mathrm{R} \$ 3,305.05$ & 33.5 & $\mathrm{R} \$ 1,666.96$ \\
Nursing Technicians & $\mathrm{R} \$ 2,636.78$ & $\mathrm{R} \$ 1,752.79$ & 33.5 & $\mathrm{R} \$ 883.99$ \\
Nursing Assistants & No longer hired & $\mathrm{R} \$ 1,589.83$ & - & - \\
\hline
\end{tabular}

Source: General Office of Human Resources - Salary table of professionals who support teaching, research and extension, in force from 05/01/2013 onwards and selection processes for nurses, nursing technicians and nursing assistants of the Foundation, in the 1st half of 2014. Minimum wage in Brazil on January 1st 2014: R\$724.00.

Table 3 - Reasons for resignation, comparison between the years 2010 and 2013 - Campinas, SP, Brazil, 2014.

\begin{tabular}{|c|c|c|c|c|c|c|c|c|c|c|}
\hline \multirow{3}{*}{$\begin{array}{l}\text { Variable } \\
\text { Reasons for resignation }\end{array}$} & \multicolumn{8}{|c|}{ Year } & \multirow{2}{*}{\multicolumn{2}{|c|}{ Total }} \\
\hline & \multicolumn{2}{|c|}{2010} & \multicolumn{2}{|c|}{2011} & \multicolumn{2}{|c|}{2012} & \multicolumn{2}{|c|}{2013} & & \\
\hline & $\mathbf{n}$ & $\%$ & $\mathbf{n}$ & $\%$ & $\mathbf{n}$ & $\%$ & $\mathrm{n}$ & $\%$ & $\mathrm{n}$ & $\%$ \\
\hline \multicolumn{11}{|l|}{ Salary } \\
\hline No & 50 & 96.2 & 56 & 88.9 & 64 & 90.1 & 34 & 91.9 & 204 & 91.5 \\
\hline Yes & 2 & 3.9 & 7 & 11.1 & 7 & 9.9 & 3 & 8.1 & 19 & 8.5 \\
\hline \multicolumn{11}{|l|}{ Another job } \\
\hline No & 47 & 90.4 & 58 & 92.1 & 67 & 94.4 & 31 & 83.8 & 203 & 91 \\
\hline Yes & 5 & 9.6 & 5 & 7.9 & 4 & 5.6 & 6 & 16.2 & 20 & 9 \\
\hline \multicolumn{11}{|l|}{ Personal problem } \\
\hline No & 39 & 75 & 47 & 74.6 & 55 & 77.5 & 24 & 64.9 & 165 & 74 \\
\hline Yes & 13 & 25 & 16 & 25.4 & 16 & 22.5 & 13 & 35.1 & 58 & 26 \\
\hline \multicolumn{11}{|l|}{ Bosses } \\
\hline No & 51 & 98.1 & 61 & 96.8 & 69 & 97.2 & 37 & 100 & 218 & 97.8 \\
\hline Yes & 1 & 1.9 & 2 & 3.2 & 2 & 2.8 & 0 & 0 & 5 & 2.2 \\
\hline \multicolumn{11}{|l|}{ Working conditions } \\
\hline No & 51 & 98.1 & 59 & 93.7 & 70 & 98.6 & 37 & 100 & 217 & 97.3 \\
\hline Yes & 1 & 1.9 & 4 & 6.4 & 1 & 1.4 & 0 & 0 & 6 & 2.7 \\
\hline
\end{tabular}




\begin{tabular}{|c|c|c|c|c|c|c|c|c|c|c|}
\hline \multirow{3}{*}{$\begin{array}{l}\text { Variable } \\
\text { Reasons for resignation }\end{array}$} & \multicolumn{8}{|c|}{ Year } & \multirow{2}{*}{\multicolumn{2}{|c|}{ Total }} \\
\hline & \multicolumn{2}{|c|}{2010} & \multicolumn{2}{|c|}{2011} & \multicolumn{2}{|c|}{2012} & \multicolumn{2}{|c|}{2013} & & \\
\hline & $\mathbf{n}$ & $\%$ & $\mathbf{n}$ & $\%$ & $\mathbf{n}$ & $\%$ & $\mathbf{n}$ & $\%$ & $\mathbf{n}$ & $\%$ \\
\hline \multicolumn{11}{|l|}{ Health } \\
\hline No & 50 & 96.2 & 60 & 95.2 & 68 & 95.8 & 35 & 94.6 & 213 & 95.5 \\
\hline Yes & 2 & 3.9 & 3 & 4.8 & 3 & 4.2 & 2 & 5.4 & 10 & 4.5 \\
\hline \multicolumn{11}{|l|}{ Interpersonal relationship } \\
\hline No & 52 & 100 & 61 & 96.8 & 71 & 100 & 37 & 100 & 221 & 99.1 \\
\hline Yes & 0 & 0 & 2 & 3.2 & 0 & 0 & 0 & 0 & 2 & 0.9 \\
\hline \multicolumn{11}{|l|}{ Adaptation problems } \\
\hline No & 52 & 100 & 62 & 98.4 & 70 & 98.6 & 36 & 97.3 & 220 & 98.7 \\
\hline Yes & 0 & 0 & 1 & 1.6 & 1 & 1.4 & 1 & 2.7 & 3 & 1.4 \\
\hline \multicolumn{11}{|l|}{ Other reasons } \\
\hline No & 22 & 42.3 & 27 & 42.9 & 28 & 39.4 & 21 & 56.8 & 98 & 44 \\
\hline Yes & 30 & 57.7 & 36 & 57.1 & 43 & 60.6 & 16 & 43.2 & 125 & 56.1 \\
\hline
\end{tabular}

Note: $(n=223)$.

Table 4 - Association between the variable age at resignation with the other variables - Campinas, SP, Brazil, 2014.

\begin{tabular}{|c|c|c|c|c|c|c|c|c|c|}
\hline Variable & $\mathbf{N}$ & Mean & SD & Minimum & Q1 & Median & Q3 & Maximum & $p$-valor \\
\hline Category & & & & & & & & & $0.9605^{*}$ \\
\hline Nurse & 47 & 33.6 & 7.6 & 25.3 & 29.4 & 31.3 & 35.6 & 56.8 & \\
\hline Technician/Assistant & 176 & 33.6 & 7.9 & 20.7 & 27.8 & 31.5 & 37.6 & 60.6 & \\
\hline Employment bond & & & & & & & & & $0.0177^{*}$ \\
\hline University & 96 & 32.5 & 8.0 & 20.7 & 27.4 & 30.6 & 35.4 & 60.6 & \\
\hline Foundation & 126 & 34.3 & 7.4 & 23.7 & 29.0 & 32.6 & 37.7 & 56.8 & \\
\hline Time working in the institution (in years) & & & & & & & & & $0.0262^{* *}$ \\
\hline Up to 1 & 123 & 33.2 & 7.6 & 20.7 & 27.4 & 31.7 & 37.1 & 56.8 & \\
\hline 2 to 4 & 53 & 32.1 & 6.9 & 23.5 & 27.9 & 30.5 & 33.7 & 55.3 & \\
\hline 5 or more & 47 & 36.2 & 8.9 & 25.5 & 29.0 & 34.3 & 42.1 & 60.6 & \\
\hline Reason: salary & & & & & & & & & $0.0893 *$ \\
\hline No & 204 & 33.9 & 7.9 & 22.7 & 28.2 & 31.5 & 37.4 & 60.6 & \\
\hline Yes & 19 & 30.6 & 6.0 & 20.7 & 26.6 & 29.9 & 33.4 & 45.6 & \\
\hline Reason: another job & & & & & & & & & $0.3572 *$ \\
\hline No & 203 & 33.8 & 8.0 & 20.7 & 27.9 & 31.6 & 37.1 & 60.6 & \\
\hline Yes & 20 & 31.8 & 6.0 & 23.7 & 27.3 & 31.0 & 34.7 & 45.4 & \\
\hline Reason: private problem & & & & & & & & & $0.0009 *$ \\
\hline No & 165 & 32.7 & 7.5 & 20.7 & 27.4 & 30.7 & 35.5 & 60.6 & \\
\hline Yes & 58 & 36.2 & 8.1 & 24.6 & 30.9 & 33.8 & 41.5 & 56.8 & \\
\hline Reason: health & & & & & & & & & $0.6758^{*}$ \\
\hline No & 213 & 33.6 & 7.6 & 20.7 & 27.9 & 31.5 & 36.9 & 60.6 & \\
\hline Yes & 10 & 34.6 & 11.3 & 23.5 & 26.6 & 29.6 & 47.1 & 54.8 & \\
\hline Reason: others & & & & & & & & & $0.0542 *$ \\
\hline No & 98 & 34.7 & 8.3 & 20.7 & 28.8 & 32.5 & 38.9 & 58.4 & \\
\hline Yes & 125 & 32.8 & 7.3 & 22.7 & 27.4 & 30.7 & 36.6 & 60.6 & \\
\hline Work force & & & & & & & & & $0.0140^{*}$ \\
\hline No & 108 & 34.7 & 7.4 & 23.7 & 28.6 & 32.8 & 38.3 & 54.8 & \\
\hline Yes & 106 & 32.8 & 8.3 & 20.7 & 27.3 & 30.8 & 35.0 & 60.6 & \\
\hline
\end{tabular}

continues.. 


\begin{tabular}{|c|c|c|c|c|c|c|c|c|c|}
\hline Variable & $\mathbf{N}$ & Mean & SD & Minimum & Q1 & Median & Q3 & Maximum & $p$-valor \\
\hline Work shift & & & & & & & & & $0.6122^{* *}$ \\
\hline Afternoon & 89 & 33.6 & 8.1 & 22.7 & 27.6 & 31.0 & 37.6 & 56.8 & \\
\hline Morning & 68 & 32.8 & 7.5 & 20.7 & 27.4 & 30.9 & 36.0 & 51.2 & \\
\hline Night & 53 & 34.0 & 8.0 & 22.7 & 28.7 & 32.0 & 36.9 & 60.6 & \\
\hline
\end{tabular}

SD: Standard deviation; Q1: First quartile; Q3: Third quartile; * p-value obtained through the Mann-Whitney test; ** p-value obtained through the Kruskal-Wallis test; Note: $(n=223)$.

\section{DISCUSSION}

This research is an original contribution due to the scarcity of studies analyzing subjects that resign an institution, since the majority of the studies is based on the professionals' intention to leave the work or the profession. Since the data collection period, the study institution did not present significant transformations; it maintains the same organizational structure, with similar financial resources, physical area, staffing and employment bonds. Therefore, the data can be considered contemporary.

The population analyzed $(n=223)$ represented $34.7 \%$ of the total number of resignations that occurred in the institution from 2010 to 2013 and were voluntary resignation, that is, it was a choice of the employee, not of the institution. Of these, $57 \%$ were linked to the hospital by a contract signed with the foundation and $43.1 \%$ with the university.

Among the professionals who left the institution, the majority (63\%) worked in another job, which gave financial support for their decision. Also, the majority were working at the hospital for a shorter period. This data indicates that, for the professionals who worked in the institution for less time, it was easier to leave it. The predominance of nursing technicians (75.3\%) corroborates the fact that many technicians got their undergraduate degree in nursing and resigned to take up a position of nurse in other institutions.

Voluntary turnover or even leaving the profession can be positive, particularly for the individual, because in some situations the nursing professional does not find possibilities for career development in the profession or in the institution they work. In addition, they often perceive their intellectual potentialities and skills underappreciated in the exercise of activities. In this sense, professionals who have invested in university studies or those who start a new career benefit from the changes as they seek new challenges and professional improvements, including financial ${ }^{(14)}$.

Regarding the work shift, the majority of the participants (41.4\%) worked in the afternoon, the period with the greatest number of professionals admitted due to greater availability of positions, since many professionals transfer to the morning and night shifts. The latter is commonly chosen for its financial attractiveness, since the nighttime extra pay is $20 \%$ of the employee's salary over the hours worked during the night, between $10 \mathrm{p} . \mathrm{m}$. and $5 \mathrm{a} . \mathrm{m}$. Another reason is compatibility with another night work. The opportunity to choose the shift and the place of work is important for the satisfaction of the professional, considering that the work shift can be a factor that contributes to problems in workers' health $^{(15)}$.

The variable age of the professionals presented a median of 31.4 years. This means that they are young adults, who are available to seek professional improvement in the labor market.

Managers who want to reduce staff turnover analyze the composition of the team regarding the integration of different generations in a harmonic way, as an approach to minimize the impact of generations. This measure helps understanding the differences of values, behaviors and desires, favors exchanges of knowledge and experiences, and establishes retention strategies ${ }^{(16)}$.

In this context, actions related to workers' health must be constantly implemented. "It is necessary to invest in prevention programs, training, health education, intervention strategies and organization of existing services"(17).

The decision to make a professional transition is based on an analysis of risks and benefits, that is, on the one hand, there is personal and professional achievement, and on the other, employment stability and salary benefits ${ }^{(18)}$.

A study conducted with 833 nurses at a university hospital in Sweden pointed out that the main reasons for leaving the job were dissatisfaction with the work (65\%), psychologically strenuous and stressful work (32\%), a wish to 'try something new' (28\%) a and limited opportunities to make a professional career $(19 \%)^{(19)}$.

Decision-making processes in management policies should consider improvements for nursing professionals, such as appreciation of the team, incentives for professional development, career plans, salaries, benefits and inclusion of professionals in the decision-making process ${ }^{(20)}$. Factors that contribute to professional satisfaction are dynamic and can be altered through organizational management and policies $^{(21-23)}$.

In the population of this study, the number of nurses hired by the foundation (78.7\%) was considerably higher than those hired by the university (21.3\%). This may be associated with the degree of dissatisfaction of the worker with the employment bond, which can lead to weak commitment to remain in the institution. Studies that correlate professional turnover with the costs of resignation and admission processes, and with the impact of this process on health users and the health team are still scarce and are important for a better understanding of the phenomenon ${ }^{(7,24)}$.

The comparison between employment bond and age was statistically significant ( $\mathrm{p}$-value $=0.0177)$, as well as the 
employment bond in relation to the salary as reason for resignation $(p$-value $=0.0412)$. Therefore, the employment bond proved to be an important factor for the turnover of nursing professionals.

A study carried out in Portugal found that human resource managerial decisions do not value the issue of employment bond in the Portuguese health system and that the professional, personal and social dimensions are not considered with due attention ${ }^{(25)}$.

Professionals who remain in the profession must find more challenging and interesting issues, especially the new generations, who seek constant and global connections in the profession, as they have lived through technological evolution, the digital age, the wireless connectivity and information networks, with interactions that transcend territorial boundaries. For this, continued education programs are fundamental, as well as incentives for self-improvement courses and graduate studies ${ }^{(26)}$.

The public teaching hospital of this study presents a teaching and learning culture and offers many opportunities for professionals to acquire new knowledge. It has always motivated professionals interested in seeking qualification, competence and quality of care. For many professionals, it is an advantage to be a public servant of the university, which may be a contributing factor for the retention of health professionals, especially nurses, since technicians who obtain a nursing degree commonly seek the opportunity to practice their profession in the category of nurses.

Therefore, the qualification of nursing management, awareness of the importance of job satisfaction, respect for the professional regarding working conditions, adaptations of the physical structure and support to the health of the worker are organizational lines of action. With this, professionals are moving towards improvements for users, for the institution, and for themselves.

\section{CONCLUSION}

In the present study, most of the professionals were young adults, in a high productivity phase, which increases willingness to seek challenges in the labor market and professional improvements. The factors that led to the decision to leave the job were having an employment bond with the foundation, age and the association of both.

The employment bond with the foundation leads to dissatisfaction due to its lower salaries and benefits and lack of employment stability. This relationship was considered a predisposing factor for the decision to resign. The decisions related to the management of hospital and university personnel should consider this factor and the analysis of the direct and indirect costs involved, along with the quality of care.

The turnover of nursing staff has direct influences on the quality and safety of the care provided to the user, since the training of the professional goes beyond the knowledge acquired in the curriculum of college courses; it also includes the knowledge of the work processes, the institutional norms and routines and the interpersonal relationships with the team, which are acquired through the institutions' commitment with continued education and with dedication and time of professional experience.

To reduce turnover, it is necessary to reduce differences in working conditions, such as different employment bonds for professionals who have the same function and perform the same activities.

The factors related to resignation are complex, and their management is a challenge for managers in their way to achieve safe and quality assistance, professional satisfaction and reduction of institutional costs.

Since the institution studied is a high complexity hospital, member of the university and a reference in the region, the working conditions provided are close to what is appropriate for the health worker, which may be different from the reality experienced in other regions. In this sense, the limitations of this study are that the results probably cannot be generalized to hospitals that do not have this profile.

\section{RESUMO}

Objetivo: Analisar os fatores relacionados à rotatividade dos profissionais de enfermagem de um hospital universitário público. Método: Estudo de caráter descritivo, exploratório, retrospectivo, com análise quantitativa, realizado com trabalhadores de um hospital universitário público. Foi utilizado um instrumento de coleta de dados próprio do serviço, aplicado no momento do processo de demissão voluntária do profissional. Resultado: Participaram do estudo 223 profissionais de enfermagem. Os fatores que predispuseram à rotatividade por demissão voluntária foram o vínculo trabalhista, a idade e a associação de ambos. A maioria dos profissionais era adulto jovem, na fase de alta produtividade, que favorece a disposição para a busca de desafios no mercado de trabalho e melhorias profissionais. Conclusão: A rotatividade é multifatorial e influenciada pelos aspectos econômicos, sociais e políticos. Minimizar as desigualdades nas condições de trabalho que geram insatisfação, como vínculos de trabalho diferentes para profissionais que exercem a mesma função e realizam as mesmas atividades, é fundamental para o decréscimo da rotatividade.

\section{DESCRITORES}

Enfermagem; Reorganização de Recursos Humanos; Satisfação no Emprego; Recursos Humanos de Enfermagem no Hospital; Gestão em Saúde.

RESUMEN

Objetivo: Analizar los factores relacionados con la rotatividad de profesionales enfermeros de un hospital universitario público. Método: Estudio de carácter descriptivo, exploratorio, retrospectivo, con análisis cuantitativo, realizado con trabajadores de un hospital universitario público. Fue utilizado un instrumento de recolección de datos propio del servicio, aplicado en el momento 
del proceso de dimisión voluntaria del profesional. Resultado: Participaron en el estudio 223 profesionales de enfermería. Los factores que predispusieron a la rotatividad por dimisión voluntaria fueron el vínculo laboral, la edad y la asociación de ambos. La mayoría de los profesionales eran adultos jóvenes, en la fase de alta productividad, lo que favorece la búsqueda por desafíos en el mercado laboral y mejorías profesionales. Conclusión: La rotatividad es multifactorial e influenciada por los aspectos económicos, sociales y políticos. Minimizar las desigualdades en las condiciones laborales que generan insatisfacción, como vínculos laborales distintos para profesionales que ejercen el mismo puesto y llevan a cabo las mismas actividades, es fundamental para el decrecimiento de la rotatividad.

\section{DESCRIPTORES}

Enfermería; Reorganización del Personal; Satisfacción en el Trabajo; Personal de Enfermería en Hospital; Gestión en Salud.

\section{REFERENCES}

1. Departamento Intersindical de Estatística e Estudos (DIEESE). Rotatividade no mercado de trabalho brasileiro [Internet]. São Paulo: DIEESE; 2016 [citado 2018 maio 11]. Disponível em: https://www.dieese.org.br/livro/2016/rotatividade2016.pdf

2. Baumann A. The impact of turnover and the benefit of stability in the nursing workforce. Geneva: International Council of Nurses; 2010.

3. Oliveira SAA, Paiva RFR. Possibilidade de diminuir o turnover da equipe de enfermagem nos serviços hospitalares. Rev Gestão Saúde. 2011;2(1):60-73.

4. Homburg V, Van der Heijden B, Valkenburg L. Why do nurses change jobs? An empirical study on determinants of specific nurses' post-exit destinations. J Nurs Manag. 2013;21(6):817-26.

5. Van der Heijden BIJ, Van Dam K, Hasselhorn HM. Intention to leave nursing. The importance of interpersonal work context, work-home interference, and job satisfaction beyond the effect of occupational commitment. Career Dev Int. 2009;14 (7):616-35.

6. Bland-Jones C. Revisiting nurse turnover costs. J Nurs Adm. 2008;38(1):11-8.

7. Halter M, Boiko O, Pelone F, Beighton $\mathrm{C}$ et al. The determinants and consequences of adult nursing staff turnover: a systematic review of systematic reviews. BMC Health Serv Res. 2017;17: 824.

8. Portoghese I, Galletta M, Battistelli A, Leiter M P. A multilevel investigation on nursing turnover intention: the cross-level role of leadermember exchange. J Nurs Manag. 2015:23(6):754-64.

9. Dawson AJ, Stasa H, Roche MA, Homer CS, Duffield C. Nursing churn and turnover in Australian hospitals: nurses perceptions and suggestions for supportive strategies. BMC Nurs. 2014;13(1):11.

10. Zavala MOQ, Klijn TP, Carrillo KLS. The quality of life of health professionals working in the prison system. Rev Latino Am Enfermagem. 2016;24:e2713.

11. LoBiondo-Wood G, Haber J. Pesquisa em enfermagem: métodos, avaliação crítica e utilização. 4a ed. Rio de Janeiro: Guanabara Koogan; 2001.

12. Pagano M, Gauvreau K. Princípios de bioestatística. 2a ed. São Paulo: Cengage Learning; 2012.

13. Brasil. Ministério da Saúde; Conselho Nacional de Saúde. Resolução n. 466, de 12 de dezembro de 2012. Diretrizes e normas regulamentadoras de pesquisas envolvendo seres humanos [Internet]. 2012 [citado 2017 ago. 12]. Disponível em: http://conselho.saude. gov.br/resolucoes/2012/Reso466.pdf

14. Flinkman $M$, Isopahkala-Bouret $U$, Salanterä S. Young registered nurses' intention to leave the profession and professional turnover in early career: a qualitative case study. ISRN Nurs. 2013;1-12. DOI: http://dx.doi.org/10.1155/2013/916061

15. Bargas EB; Monteiro MI. Factors related to absenteeism due to sickness in nursing workers. Acta Paul Enferm. 2014;27(6)533-8.

16. Tourangeau AE, Thomson H, Cummings G, Cranley LA. Generation-specific incentives and disincentives for nurses to remain employed in acute care hospitals. J Nurs Manag. 2013; 21(3):473-82.

17. Lelis CM, Battaus MRB, Freitas FCT, Rocha FLR, Marziale MHP, Robazzi MLCC. Work-related musculoskeletal disorders in nursing professionals: an integrative literature review. Acta Paul Enferm. 2012;25(3):477-82.

18. Tummers LG, Groeneveld SM, Lankhaar M. Why do nurses intent to leave their organization? A large-scale analysis in long-term care. J Adv Nurs. 2013;69(12):2826-38

19. Gardulf A, Söderström IL, Orton ML, Eriksson LE, Arnetz B, Nordström G. Why do nurses at a university hospital want to quit their jobs? J Nurs Manag. 2005;13(4):329-37.

20. Melo MB, Barbosa MA, Souza PR. Job satisfaction of nursing staff: integrative review. Rev. Latino Am Enfermagem. 2011;19(4):1047-55.

21. Twigg D, McCullough K. Nurse retention: a review of strategies to create and enhance positive practice environments in clinical settings. Int J Nurs Stud. 2014;51(1):85-92.

22. World Health Organization. Global Strategy on Human Resources for Health: Workforce 2030 [Internet]. Geneva: WHO; 2015 [cited 2018 Jan 23]. Available from: http://www.who.int/hrh/resources/glob-strat-hrh_workforce2030.pdf

23. Gyllensten K, Andersson G, Muller H. Experiences of reduced work hours for nurses and assistant nurses at a surgical department: a qualitative study. BMC Nurs. 2017;16:16.

24. Hayes LJ, O'Brien-Pallas L, Duffield C, Shamian J, Buchan J, Hughes F, et al. Nurse turnover: a literature review - an update. Int J Nurs Stud. 2012;49(7):887-905. 
25. Poeira A, Mamede RP. Os fatores determinantes da rotatividade externa dos enfermeiros: vínculo contratual, incentivos salariais ou reconhecimento profissional. Rev Enf Ref. 2011; Coimbra, serlll (4):107-14.

26. Balabanian YCC, Pereira RMC. Impacto das diferentes gerações no ambiente de trabalho. In: Monteiro I, Iguti AM, organizadoras. Trabalho, saúde e sustentabilidade: construindo a cidadania. Campinas; BFCM/Unicamp; 2016. p. 129-34.

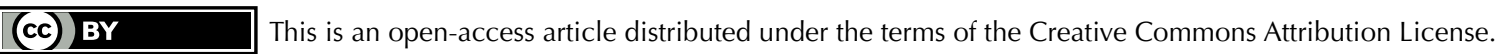

